\title{
The Effect of Dietary Sodium Humate Supplementation on Nutrient Digestibility in Growing Pigs
}

\author{
Bohumila Písaříková, Zdeněk Zralý, Ivan Herzig ${ }^{1}$ \\ Veterinary Research Institute, Brno, Czech Republic \\ ${ }^{1}$ Department of Nutrition, Animal Husbandry, and Animal Hygiene, Faculty of Veterinary Hygiene and Ecology, \\ University of Veterinary and Pharmaceutical Sciences, Brno, Czech Republic
}

Received February 9, 2009

Accepted December 3, 2009

\begin{abstract}
A total of 16 crossbred (Large White $\times$ Landrace) castrated male pigs averaging $30.0 \pm 2.5 \mathrm{~kg}$ were used in two trials $(2 \times 8$ pigs $)$ to determine apparent nutrient digestibility. The control group received feed mixture consisting of wheat and barley. In the experimental group, 3\% proportion of wheat was replaced by sodium humate. The results of nutrient digestibility showed significantly lower $(P<0.01)$ digestibility of crude protein $(82.2 \pm 1.92$ vs. $87.9 \pm 2.05 \%)$ and crude fat $(32.0 \pm 2.81$ vs. $49.3 \pm 2.25 \%)$ in the control group compared to the experimental group. Nonsignificantly lower digestibility was found in dry matter $(86.0 \pm 3.20$ vs. $89.2 \pm 3.08 \%)$, crude fibre $(34.3 \pm 3.64$ vs. $37.6 \pm 2.86 \%)$ and ash $(56.1 \pm 2.49$ vs. $58.1 \pm 2.47 \%)$. The results confirmed sorption ability of humate fed to pigs. The decrease of coefficients of apparent digestibility in nitrogen substances can lead to decreased amounts of ammonia into the environment of the stables.
\end{abstract}

Apparent digestibility, faeces, sorption

The natural, high-molecular heteropolycondensates formed by biochemical transformation of plant residues and animal tissues during the process of humification, are generally termed humus. Humic substances are highly-abundant organic compounds formed in soils. They are natural constituents of soil, drinking water, sea water and the food chain. Major components of humic substances are humic, fulvic, and ulmic acids, which are essential for plant growth (Stevenson 1994). They have a three-dimensional structure and contain various functional groups, predominantly hydroxyl, carboxyl, carbonyl, amine, amide and sulphhydryl groups. The European Agency for the Evaluation of Medicinal Products (EAEMP) and its Committee for Veterinary Drugs issued a report in which they recommend to include humic acid and its sodium salt into the Annex II Council Regulation (EEC) No 2377/99 and allow their use in all food animals for oral administration (EMEA 1999).

Humic acids are used in horses, ruminants, pigs and poultry at an oral dose level of 500 $2000 \mathrm{mg} / \mathrm{kg}$ of body weight for the treatment of diarrhoea, dyspepsia and acute intoxication (EMEA 1999). Protective effects of humic acids on intestinal mucosa have been confirmed as well as anti-inflammatory, adsorption, antitoxic and antimicrobial properties (Stephenko et al. 1991; Lange et al. 1996; Yoruk et al. 2004). Significant effect of humic acids on reduction of biological availability of lead in chickens was discovered (Zralý et al. 2008). Data from the literature report the effects of humic acids on growth and health protection capacity changing some physiological functions in animals. However, also contradictory findings in piglets have been reported (Schuhmacher and Gropp 2000).

The idea of using humates as feed additives in animal nutrition is new. Humic acids stabilize the intestinal microflora, ensuring an improved nutrient utilization and feed efficiency. This leads to an increase in the live weight of animals without increasing the amount of feed (Bailey et al. 1996; Yasar et al. 2002; Ceylan and Ciftci 2002; Karaoglu et al. 2004; Islam et al. 2005). At the same time, nitrogenous wastes and odour are reduced as a result of higher feed conversion and enhanced nitrogen adsorption by

Address for correspondence:

MVDr. Zdeněk Zralý, CSc.

Veterinary Research Institute

Hudcova 70, 62100 Brno

Czech Republic
Phone:. +420533331612

Fax: +420541211229

E-mail: zraly@vri.cz

http://www.vfu.cz/acta-vet/actavet.htm 
the animals (Suchý et al. 1999; Shi et al. 2001; Ji et al. 2006). Decrease of ammonia emissions by $30 \%$ in the environment of the stables as a result of humate applications into feeds was reported by Herzig et al. (2001) in chicken broilers. Reduction of air ammonia by 16 to $18 \%$ was also reported by $\mathrm{Ji}$ et al. (2006) after the application of HS1 or HS4 (Humatech Inc., Mesa, AZ) into the diets for pigs.

Nutrient digestibility and nitrogen balance in pigs at the diet supplementation with Humobentofet (25\% extracted rape oil, 55\% modified bentonite, 20\% Humokarbowit plus antioxidant) was studied by Korniewicz et al. (1999), who did not find any significant effect on digestibility of crude protein, but at 5\% supplementation, better conversion of the absorbed nitrogen was observed. Higher nitrogen retention, feed intake and improved feed conversion after humic acid application to rats was reported in two experiments of Yasar et al. (2002). Only sporadic data on the effect of dietary humate on nutrient digestibility in pigs can be found in the literature.

The objective of our study was to investigate the effect of $3 \%$ sodium humate in the diet of growing pigs on balance digestibility of nutrients and selected biochemical indicators in blood plasma.

\section{Materials and Methods}

Animals and diets

A total of $16(2 \times 8)$ crossbred (Large White $\times$ Landrace) castrated male pigs, with the initial average weight $30.0 \pm 2.5 \mathrm{~kg}$, were used in two balance experiments. Control group (C) received feed compound based on wheat and barley, and in the experimental group ( $\mathrm{HNa}), 3 \%$ of wheat was replaced by sodium humate (Table 1). Feed compounds were designed for the first stage of fattening of meat type pigs with $56 \%$ proportion of muscles as isonitrogenous and isoenergetic (Šimeček et al. 2000). Sodium humate (JV 24) offered by VÚAnCh, Ústí n. Labem, Czech Republic was used in our experiment.

Experimental design

The animals were housed in accredited stables of the Veterinary Research Institute, Brno under required zoohygienic conditions. The average temperature in the stable was $23.7 \pm 1.2{ }^{\circ} \mathrm{C}$ and relative humidity was $69.5 \pm 5.8 \%$ during the experiment. Prior to the experiment, the animals were dewormed (Ivomec, inj., Agvet, USA). The preparation period of the experiment took 11 days. Nutrient digestibility was determined during 5 days using the indicator of insoluble ash in $4 \mathrm{M} \mathrm{HCl}$ in pigs housed in metabolic cages. The faeces were collected from individual animals twice a day at the amount of approximately $100 \mathrm{~g}$, stabilized by $10 \% \mathrm{HCl}$, and chloroform, and were kept in the refrigerator until analyses. After termination of the balance period, the faecal samples were homogenized and dry matter and crude protein were determined. For further analyses, the faeces were dried at $60^{\circ} \mathrm{C}$ and ground. Apparent digestibility of dry matter, crude fat, crude fibre, ash, nitrogen free extractives and organic matter were calculated. Live weight was determined at the beginning of the experiment and at its termination. Body mass were calculated at individual and group bases. Feed conversion rate was determined based on group feed consumption and live weight gains. After termination of the balance period, blood was collected from v. cava cranialis to determine selected biochemical indicators of blood plasma.

Chemical analysis

Ground samples of feed compounds and faeces were analysed for the content of dry matter, crude protein $(\mathrm{N} \times 6.25)$, crude fat, crude fibre and ash using the AOAC methods (2001). The samples of experimental diets and faeces were also analysed for the content of insoluble ash in 4M HCl (AOAC 2001). The concentrations of total proteins, albumin, glucose, cholesterol, alkaline phosphatase (ALP), aspartate and alanine aminotransferase (AST, ALT), gamma-glutamyltransferase (GMT), calcium and phosphorus in blood plasma were determined spectrophotometrically using Bio-La-Tests (PLIVA - Lachema Brno Ltd., Czech Republic). Sodium was determined in blood plasma by the method of emission flame spectrometry.

Statistical analyses

The results obtained were processed by statistical and graphic software STAT Plus (VRI, Brno, Czech Republic). Data were analysed using the basic statistical characteristics; the mean differences were tested by $t$-test.

\section{Results and Discussion}

The contents of crude protein were 158.6 and $160.1 \mathrm{~g} / \mathrm{kg}$ in the experimental and control diet, respectively. The metabolisable energy for pigs (MEp) was 12.6 and $13.0 \mathrm{MJ} / \mathrm{kg}$; the ration of lysine and MEp was balanced $0.75(\mathrm{HNa})$ and $0.73(\mathrm{C}) \mathrm{g} / \mathrm{MJ}$ (Table 1). We 
Table 1. Composition of feed mixtures for pigs

\begin{tabular}{|l|c|c|}
\hline \multirow{2}{*}{ Compound (\%) } & \multicolumn{2}{|c|}{ Diet } \\
\cline { 2 - 3 } & Contol & HNa group \\
\hline Wheat & 63.2 & 60.2 \\
\hline Barley & 20.0 & 20.0 \\
\hline Extracted soya meal 46\% CP & 13.1 & 13.1 \\
\hline Biolysine 65\% & 0.64 & 0.64 \\
\hline D,L-methionine 100\% & 0.06 & 0.06 \\
\hline L-threonine 100\% & 0.11 & 0.11 \\
\hline BOLIFOR ${ }^{\circledR}$ MCP-F* & 0.85 & 0.85 \\
\hline A1-CDP-HD & 0.25 & 0.25 \\
\hline Feeding salt & 0.38 & 0.38 \\
\hline Ground limestone & 1.37 & 1.37 \\
\hline Sodium humate & - & 3.00 \\
\hline Nutrient composition $(\mathrm{g} / \mathrm{kg})$ & 877.0 & 877.7 \\
\hline Dry matter & 160.1 & 158.6 \\
\hline Crude protein & 15.7 & 15.3 \\
\hline Fat & 25.7 & 25.1 \\
\hline Fibre & 29.9 & 40.5 \\
\hline Ash & 645.6 & 638.2 \\
\hline Nitrogen free extractives & 847.1 & 838.3 \\
\hline Organic matter & 13.0 & 12.6 \\
\hline MEp (MJ/kg) & 0.73 & 0.75 \\
\hline Lysine /MEp (g/MJ) & \multicolumn{2}{|c|}{} \\
\hline
\end{tabular}

*Monocalcium Phosphate, Monohydrate, Feed Grade

Composition of A1-CDP-HD (kg): 335000 IU vitamin A, 45000 IU vitamin $\mathrm{D}, 125 \mathrm{mg}$ vitamin $\mathrm{K}, 2665 \mathrm{mg}$ vitamin $\mathrm{E}, 5.3 \mathrm{mg}$ vitamin $\mathrm{B} 1$, $165 \mathrm{mg}$ vitamin B2, $14 \mathrm{mg}$ vitamin B6, $1.10 \mathrm{mg}$ vitamin B12, $165 \mathrm{mg}$ niacin, $250 \mathrm{mg}$ pant. calcium, $1000 \mathrm{mg}$ cholinchloride, $0.8 \mathrm{mg}$ biotin, $6600 \mathrm{mg}$ vitamin C, $110 \mathrm{~g}$ L-lysine HCl, $33 \mathrm{~g} \mathrm{D}, \mathrm{L}-$ methionine, $55 \mathrm{~g}$ L-threonine, $15 \mathrm{mg} \mathrm{Co,} 65 \mathrm{mg} \mathrm{J}, 11 \mathrm{mg} \mathrm{Se}, 660 \mathrm{mg} \mathrm{Cu}, 1585 \mathrm{mg} \mathrm{Mn}$, $3500 \mathrm{mg}$ Zn, $2080 \mathrm{mg}$ Fe, $56 \mathrm{~g} \mathrm{Na}, 12 \mathrm{~g} \mathrm{Mg}, 80 \mathrm{~g} \mathrm{P}, 205 \mathrm{~g} \mathrm{Ca}, 833 \mathrm{mg}$ Endox, 11250 mg Bio-plus 2B, 2900 mg Natuphos 5000G, $665 \mathrm{mg}$ Saccharin

recorded during the experiment between the experimental and control group but the weight gain and feed conversion were lower by $4.9 \%(0.41 \pm 0.21$ vs. $0.43 \pm 0.16 \mathrm{~kg} /$ day $)$ and by $5.8 \%$ (2.90 vs. $2.74 \mathrm{~kg} /$ day), respectively, in the experimental group compared to control group.

Crude protein digestibility was significantly lower $(P<0.01)$ in the experimental group $(82.2 \pm 1.92$ vs. $87.9 \pm 2.05 \%)$ compared to the control as well as crude fat $(32.0 \pm 2.81$ vs. $49.3 \pm 2.25 \%$ ) (Fig. 1). Further, non-significantly lower values of dry matter digestibility $(86.0 \pm 3.20$ vs. $89.2 \pm 3.08 \%)$, fibre $(34.3 \pm 3.64$ vs. $37.6 \pm 2.86 \%)$, ash $(56.1 \pm 2.49$ vs. $58.1 \pm 2.47 \%)$, nitrogen free extractives $(91.9 \pm 2.54 \mathrm{vs} .93 .8 \pm 2.36 \%)$, and organic matter $(87.4 \pm 2.49$ vs. $90.3 \pm 3.07 \%)$ were found in the experimental group compared to the control. The results obtained are in accordance with the data reported by Korniewicz et al. (1999). The decrease of the digestibility values can be associated with the ability of humate to construct different types of binding interactions that can affect nutrient resorption. In terms of possible use of $\mathrm{HNa}$ as a nutritional additive, the concentration tested appears to be too high and further experiments are needed to find the optimum dose of humate in feed mixtures.

Humic acid contains a large amount of nitrogen in its molecule, has stronger absorption ability to amide and causes that the non-protein amide is used more effectively 


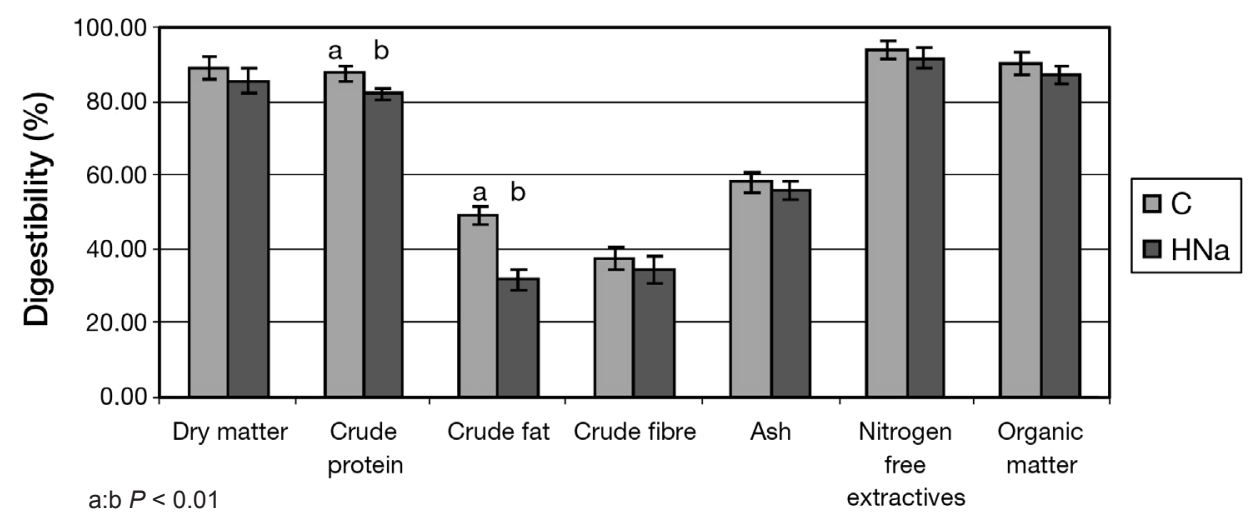

Nutrients

Fig. 1. Nutrient digestibility in pigs

(Anonymous 2007). Absorption ability of humic acid results in slower passage of gut contents, prolonged digestion period and increase of anabolic processes (Korniewicz et al. 1999; Suchý et al. 1999; Anonymous 2007). The residues of humic acid absorb ammonia in the intestines, which only decreases bad smell but also increases the efficiency of faeces as fertilizers (Herzig et al. 2001; Shi et al. 2001, Ji et al. 2006).

The effect of diets on biochemical indicators of blood plasma of pigs is shown in Table

Table 2. Selected biochemical indicators of blood plasma in pigs

\begin{tabular}{|l|c|c|}
\hline \multirow{2}{*}{ Indicator } & \multicolumn{2}{|c|}{ Diet } \\
\cline { 2 - 3 } & Control & HNa group \\
\hline Total protein $(\mathrm{g} / \mathrm{l})$ & $54.3 \pm 3.84$ & $53.8 \pm 4.26$ \\
\hline Albumin $(\mathrm{g} / \mathrm{l})$ & $16.0 \pm 2.60$ & $15.8 \pm 3.54$ \\
\hline Glucose $(\mathrm{mmol} / \mathrm{l})$ & $5.75 \pm 0.96$ & $5.17 \pm 0.88$ \\
\hline ALP $\mu \mathrm{kat} / \mathrm{l}$ & $2.00 \pm 0.41$ & $1.98 \pm 0.34$ \\
\hline AST $\mu \mathrm{kat} / \mathrm{l}$ & $0.60 \pm 0.29$ & $0.67 \pm 0.16$ \\
\hline ALT $\mu \mathrm{kat} / \mathrm{l}$ & $1.53 \pm 1.37$ & $1.11 \pm 0.24$ \\
\hline GMT $\mu \mathrm{kat} / \mathrm{l}$ & $0.37 \pm 0.13$ & $0.37 \pm 0.11$ \\
\hline Total lipids $(\mathrm{g} / \mathrm{l})$ & $2.59 \pm 0.43$ & $2.35 \pm 0.37$ \\
\hline Total cholesterol (mmol/l) & $2.68 \pm 0.54$ & $2.58 \pm 0.34$ \\
\hline Calcium $(\mathrm{mmol} / \mathrm{l})$ & $2.81 \pm 0.29$ & $2.68 \pm 0.09$ \\
\hline Phosphorus inorganic $(\mathrm{mmol} / \mathrm{l})$ & $2.84 \pm 0.15$ & $2.77 \pm 0.14$ \\
\hline Sodium $(\mathrm{mmol})$ & $135 \pm 27.0$ & $148 \pm 36.4$ \\
\hline
\end{tabular}

2. No significant difference in selected characteristics of protein, fat, carbohydrate and mineral metabolism was found between the experimental group of animals with dietary sodium humate and the control. Biochemical indicators were within the reference range in all animals (Tlučhoř 2001) which suggests a balanced homeostasis of the organism. Sodium concentrations in blood plasma also give evidence of its balanced intake. No symptoms of clinical diseases also confirm beneficial effects of humate on

animal health. A highly positive effect of humic substances supplementation on mortality decreasing in experimental pigs was reported by Ji et al. (2006).

Our results confirmed sorption ability of the tested humate. The decrease of apparent digestibility can mean, in the case of nitrogenous substances, a decrease of ammonia emissions into the environment of stables. The use of $\mathrm{HNa}$ as a nutritious additive requires further experiments to determine the optimum dose of humate in the feed mixture.

\section{Vliv humátu sodného na stravitelnost živin u rostoucích prasat}

Ve dvou bilančních pokusech bylo použito $16(2 \times 8)$ kř́řženců Bílé ušlechtilé $\times$ Landrace kastrovaných kanečků $\mathrm{s}$ iniciální prüměrnou hmotností 30,0 $\pm 2,5 \mathrm{~kg}$. Kontrolní skupina (C) přijímala krmnou směs na bázi pšenice a ječmene, u pokusné skupiny (HNa) byly $3 \%$ 
pšenice nahrazeny humátem sodným. Oproti kontrolní skupině byla na základě výsledků stravitelnosti živin zjištěna u pokusné skupiny signifikantně nižší $(P<0,01)$ stravitelnost dusíkatých látek $(82,2 \pm 1,92$ vs $87,9 \pm 2,05 \%)$, a tuku $(32,0 \pm 2,81$ vs $49,3 \pm 2,25 \%)$, nevýznamně nižší stravitelnost sušiny $(86,0 \pm 3,20$ vs $89,2 \pm 3,08 \%)$, hrubé vlákniny $(34,3$ $\pm 3,64$ vs $37,6 \pm 2,86 \%)$ a popela $(56,1 \pm 2,49$ vs $58,1 \pm 2,47 \%)$. Výsledky pokusu dokládají sorpční schopnosti zkrmovaného humátu. Snížení koeficientů bilanční stravitelnosti u dusíkatých látek ve svém důsledku může znamenat snížení emisí amoniaku do stájového prostředí.

\section{Acknowledgement}

This study was supported by the Ministry of Agriculture of the Czech Republic (project MZE-0002716202) and MSMT (project AdmireVet No. ED 006/01/01).

\section{References}

Anonymous 2007: The functional mechanism of sodium humate on animals [2007-10-07]; Agroland Bio-Tech Co., Ltd [online] http://www.agroland.com.cn/en/ArticleShows.asp?ArticleID=4289> [2009-01-15]

AOAC - Association of Official Analytical Chemists International 2001: Official Methods of Analalysis. $17^{\text {th }}$ ed. AOAC Inc., Arlington, USA

Bailey CA, White KE, Domke SL 1996: Evaluation of Menefee HumateTM on the performance of broilers. Poult Sci 75: $84 \mathrm{pp}$

Ceylan N, Ciftci I 2002: The effect of some alternative feed additives for antibiotic growth promoters on the performance and gut microflora of broiler chicks. Turk J Vet Anim Sci 27: 727-733

EMEA 1999: Committee for veterinary medical products. Humic acids and their sodium salts. http:/www.emea. europa.eu/pdfs/vet/mrls/055499en.pdf (accessed February 1999)

Herzig I, Kozler J, Písaříková B, Fengl M, Jursa V 2001: Effects of a humine acid-based sorbent on the concentration of ammonia in broiler houses. Archiv Geflug 65: 246-250

Islam KMS, Schuhmacher A, Gropp JM 2005: Humic acid substances in animal agriculture. Pakistan J Nutr 4: $126-134$

Ji F, Mcglone JJ, Kim SW 2006: Effects of dietary humic substances on pig growth performance, carcass characteristics, and ammonia emission. J Anim Sci 84: 2482-2490

Karaoglu M, Macit M, Nurinisa E, Durdag H, Turgut L, Bilgin CÖ 2004: Effect of supplemental humate at different levels on the growth performance, slaughter and carcass traits of broilers. Poult Sci 3: 406-410

Korniewicz D, Korniewicz A, Dobrzanski Z, Kolacz R, Czarnik-Matusewicz H, Paleczek B 1999: Efficiency of mineral-fat supplement Humobentofet in boar and gilt nutrition. Ann Anim Sci - Rozc Nauk Zoot 26: 275-289

Lange N, Kühnert M, Haase A, Höke H, Seubert B 1996: Studies concerning the resorption properties of a low molecular humic substance after single oral application to rats. Dtsch tierärztl Wschr 103: 134-135

Schuhmacher A, Gropp JM 2000: Effect of humic acids on health state and performance of weaners (in German). Proc Soc Nutr Physiol 9: 77 pp

Shi Y, Parker DB, Cole NA, Auvermann BW, Mehlhorn JE 2001: Surface amendments to minimize ammonia emissions from beef cattle feedlots. Trans Am Soc Agric Eng 44: 677-682

Stephenko LM, Zhorina LV, Kravtsova LV 1991: The effect of sodium humate on metabolism and resistance in highly productive poultry (in Russian). Nauch Dokl Vyss Shk Biol Nauk 10: 90-95

Stevenson FJ 1994: Humus chemistry-genesis, composition, reactions. John Wiley \& Sons, New York, NY: $443 \mathrm{p}$.

Suchý P, Herzig I, Písaříková B 1999: The use of sorbents on the basis of humic acids to reduce ammonia levels in stable environment. Vet Med Czech 44: 331-338

Šimeček K, Zeman L, Heger J 2000: Nutrient requirement and tables of nutritional values of pig feeds (in Czech). MZLU Brno and VÚVZ Pohořelice: $125 \mathrm{pp}$

Tlučhoř V 2001: Evaluation of biochemical parameters in veterinary medicine from the standpoint of an individual and a herd (in Czech). Krmivářství 5: 18-20

Yasar S, Gokcimen A, Altuntas I, Yonden Z, Petekkaya E 2002: Performance and ileal histomorphology of rats treated with humic acid preparations. J Anim Physiol Anim Nutr 86: 257-264

Yoruk MA, Gul M, Hayirli A, Macit M 2004: The effect of supplementation of humate and probiotic on egg production and quality parameters during the late laying period in hens. Poult Sci 83: 84-88

Zralý Z, Písaříková B, Trčková M, Navrátilová M 2008: The effect of humic acids on lead accumulation in chicken organs and muscles. Acta Vet Brno 77: 439 - 445 
